femoral form-in a girl, aged eight years." Mr. Murray's statistics, as well as my own, show that these diverticula are of much more frequent occurrence in the middle-aged and old than in the young - a fact pointing clearly to their acquisition during the course of post-natal, not of pre-natal, life as Mr. Russell supposes.

In his last contribution to THE LANCET ${ }^{5} \mathrm{Mr}$. Russell is able to state " that there is not a single fact at our disposal which, if scrutinised closely enough, is not at once in revolt against the traditional view as to the etiology of hernia and in complete harmony with the saccular theory." The opposite is the case. There is positive proof that embryonic femoral diverticula are purely imaginary; the positive proof that they are not found in the newly born and the further proof that they become common only as middle life and old age are reached, is clear proof that femoral sacs are not the result of developmental processes affecting the embryo or fœtus but of pathological processes affecting the adult.

It is scarcely conceivable that a "saccular theory" of hernia could be formulated by anyone familiar with the anatomy of the groin or with the extent to which the lower contents of the abdomen are subject to pressure during the lifting of heavy weights, periods of straining, or in prolorged fits of coughing. Of all the layers which form the belly wall in the neighbourbood of the femoral ring or over the internal abdominal ring, the peritoneum offers the least resistance to the formation of a hernia. So lax is the sub. peritoneal tissue in this region, so moveable is the peritoneum, that a very slight degree of pressure is enough to force the peritoneum ontwards in the form of a sac, provided there is a break in the continuity or localised weakness in the belly wall at the point where the pressure is applied. In many people the femoral ring and internal abdoninal ring are the sites of deficiency or weakness; they are the weakest points in the belly wall and therefore the first to give way under intra-abdominal strain. Instead of "all the facts at our disposal being in revolt against the traditional view" of hernia they are in complete agreement with it and cannot be harmonised with Mr. Russell's theory; we know that the femoral and internal abdominal rings are weak points : we know that in certain conditions the contents of the lower abdomen become subjected to high pressure, sufficient to force the abdominal contents through these weak points and carry the peritoneum in front in the form of a sac. All the evidence at our disposal points to the coincident formation or pre-formation of a peritoneal sac as the least essential point in the pathology of hernia ; the essential fact is the weakness or deficiency of the abdominal wall through which a diverticulum of the peritoneum can be so easily forced. Every fact, embryological, anatomical, and pathological, when closely scrutinised, is in revolt against Mr. Russell's theory.

It may appear to Mr. Russell or to his supporters that although the "saccular theory" of hernia is inapplicable to the femoral form it may still be valid for all the forms of hernia that occur within the inguinal canal. It is clear from the description which Mr. Russell gives of the development of that canal ${ }^{6}$ that he has not a first-hand knowledge of the manner in which the canal is formed. It is only fair to Mr. Russell to quote his own words :-

The slender tube of peritoneum is at this time imbedded in a mass of mesoblastic tirsue that is performing rapid evolutions in its progress towards the ultimate formation of a perfect inguinal region and scrotum. As a result of this circumstance apparently we tind that the funicular process becomes, as it were, caught here and there

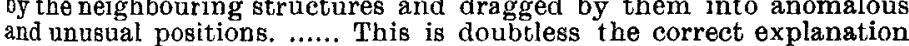
and unusual positions. ..... This is doubtless the correct explanation of the great rariety of secondary sacculations and other irregularities hat are observed in the funicular process with extreme frequency. we are indebted for all the named varieties of inguinal hernia.

It is strange that one who seeks to revolutionise our conception of a whole field of surgical knowledge on a basis of embryological discovery has not sought to make himself familiar with the current use of even the most elementary embryological terms. The term "funicular process," employed, so far as I know, solely as a term for the tube of peritoneum which conrects the tunica vaginalis with the peritoneal cavity, he employs as the designation of the whole processus vaginalis. I rave examined the process us vaginalis in upwards of 100 human fœtuses, but I have never seen any evidence of "a mass of mesoblastic tissue that is performing rapid evolutions," nor have seen, read, or heard of anyone

$$
\begin{aligned}
& 4 \text { Brit. Med. Jour., Oct. 1st, } 1904 . \\
& 5 \text { THE LA SCrT, Nov. 3rd, 1906, p. } 1198 .
\end{aligned}
$$$$
6 \text { THE LANCET, Nov. 3rd, } 1906 .
$$

who has seen, the funicular process " caught here and there by the neighbouring structures and dragged by them into anomalous and unusual positions." We will willingly wait until Mr. Russeil can supply us with a more accurate de. scription of "this proneness to irregular sacculation of the funicular process." Until that time it will serve no useful purpose to discuss the embryological basis on which rests Mr. Russell's saccular theory of hernia.

I am, Sirs, yours faithfully,

London IIospital, E., Nov. 3rd, 1906.

A. KEITH.

\section{SO-CALLED VIRULENT SYPHILIS AND ITS TREATMENT.}

\section{To the Editors of THE LANCET.}

SIRs,-May I be allowed to make a few remarks on Colonel F. J. Lambkin's interesting article in THE LANCET of Nov. 3rd? 1. In the first place Colonel Lambkin defines "rnalignant syphilis" as "that form of the disease which is associated with an indurated sore, which, probably becoming phagedænic, is followed by rupial ulceration of the skin, nodes, caries, and necrosis of bone, and later by visceral lesions, cachexia, anæmia, and profound debility." I venture to point out that such cases would be classed by most of the continental syphilologists as syphilis gravis, in distinction to syphilis maligna, which is generally understood to mean an early tendency to severe ulceration of the skin occurring soon after the chancre. Professor Neisser ${ }^{1}$ defines malignant syphilis as " a severe form of the disease characterised by certain symptoms differing rather in their nature than in mere severity from the usual forms of the malady. It will be understood, therefore that every case of severe syphilis must not be included under the designation of malignant. For example, when syphilis is rendered a dangerous affection on account of the relation of the organs attacked, or by reason of some previously existing morbid condition, the term 'malignant' is not appropriate. The term 'syphilis gravis' is more suitable in such forms of the disease." 2. Colonel Lambkin gives the following causes of malignancy : poor physique, bad hygiere, malaria, renal disease, alcoholism, insufficient or delayed treatment. Neisser, however, regards malignancy as due to a "peculiar susceptibility of the affected person," and denies that it is due to debility, alcoholism, or to such diseases as gout, diabetes, or nephritis. Haslund ${ }^{2}$ suggested the name "syphilis ulcerativa procox" instead of syphilis maligna, as the latter term has been confounded with cases of early or precocious tertiary syphilis. 3. Colonel Lambkin states that "some of the greatest authorities" advise mercury to be withheld till secondary symptoms appear. I think it is generally agreed by the great majority of syphilologists that syphilis should be treated as soon as it is diagnosed, a point which was urged by Fournier many years ago. In cases of doubtful chancre it is, no doubt, wise to postpone mercurial treatment, but such cases should now become less since the chancre can be diagnosed by the presence of the spirochæta pallida (assuming this to be the pathogenic microbe of syphilis). 4. Colonel Lambkin states "that mercury given internally over any lengthened period in any case of syphilis, by upsetting the digestive apparatus, sooner or later brings about depletion of the system generally." Against this are the facts that Professor Fournier and Mr. J. Hutchinson have treated their patients as a routine method by the ingestion of mercurial pills (protoiodide and grey powder respectively) for upwards of 40 years and have seen no reason to abandon this method. Although admitting that the method of intramuscular injections of mercury is a most valuable addition to the therapeutics of syphilis (especially in the case of the i rmy and navy or when dealing with batches of prostitutes), I think that the method of ingestion is still the most suitab'e for the prolonged administration of mercury over several years. Private patients can hardly be expected to indure mercurial injections for the whole period of treatment (which should last three or four years), and this method should be reserved for the periods during which active symptoms are present or when grave complications arise. As Fournier ${ }^{3}$ remarks, "mercury, when properly administered, always enters the system whatever the method adopted, and the

\footnotetext{
1 British Journal of Dermatology, January, 1897. Traitement de la Syphilis, second edition, 1902
} 
hypodermic method, from this point of view, is not distinctly superior to any other method."

I am, Sirs, yours faithfully,

New Cavendish-street, W., Nov. 5th, $1906 . \quad$ C. F. MARSHALL.

\section{THE SOILING OF THE LOAF.}

7o the Editors of THE LANCET.

SIRS,-I have no doubt many a householder interested in public-health questions is grateful to you for your recent article under the above heading. In this conservative old country it seems to be quite possible that public opinion has never been directed to this evil since Englishmen began to consider questions of domestic health, and since paper bags have been so inexpensive. Why should not the baker deliver a loaf of bread in a bag just as if it were a bun or a cake? Why should bread be taken to the customers' houses for seleotion? This is not done with regard to other articles of food supplied from shops, though it is a habit of street hawkers. Why does the cook or other servant want to prod the loaves on delivery with her unwashed hands? To feel if the selected loaf is crisp, to make certain that the baker is not substituting a stale article for a fresh one, or is it merely a conventional excuse for prolonging a flirtatious interview? You point out the risk which bread runs from contact with the baker's coat or handkerchief or with the mud or dust of the street, but there are other dangers to which the basket of unprotected bread may be subjected. A careful boy hangs his basket on the area railings while he is chatting with the maids, but it is no uncommon thing to see a basket waiting on a muddy, sputum-stained (? tuberculous) pavement, exposed to the urinary attentions of canine passers-by. For the needs of my own household a provider has been found who sends us "Farm-house" bread, each loaf wrapped in a paper bag, for which we pay nothing extra. I presume there are many bakers who would do this if invited by their clients. I am, Sirs, yours faithfally, F. M. SaNDWITH, M.D. Durh.

Cavendish-square, W., Nov. 13th, 1996

\section{To the Editors of THE LANCET.}

SIRS, - While you are advocating more purity in our bread-supply, any morning between 6 and 7 o'clock at a large bakery establishment there may be seen standing on the pavement in shallow trays, not so high as the loaves they contain, the morning delivery awaiting storage in the carts. The rotatory road-sweeping machines pass by, scattering upon them in dry weather the dust of the street, and the pavement sweeper goes in and ont among the trays with his brush, completing the dosage of germs. One morning lately I saw an assistant throw one of the loaves into a street corner at a passing cat, which loaf was then carelessly included in the stock. As this sort of thing may be of common practice in London, as you have the interest of the community at heart you may be glad to have this testimony from a frequent eyewitness who regrets he has not the power you have in the matter to put a stop to it. I know nothing of the bakery or its owners who probably themselves are quite unaware of the evils involved in it.

I am, Sirs, your obedient servant,

Clarence Gate, N.W., Nov. 9th, $1906 . \quad$ H. J. HUGH, Major.

\section{MORAU AND "JENSEN'S TUMOUR."}

\section{To the Editors of THE LANCET.}

SiRS,-Will you allow me to call attention to a typographical error in the abstract of my recent communication to the Pathological Society, "What is 'Jensen's Tumour'?" 1 in which the discoverer and original investigator of this interesting malady is referred to as Moran, instead of Morau? The just claims of Morau as the discoverer of this malady have been so generally overlooked in this country and in Germany that the malady he discovered and experimentally investigated is now commonly known as "Jensen's tumour," and this kind of misconception has lately received its apotheosis at the hands of the Council of the Royal College of Surgeons, who have just awarded the Walker prize to Jensen as its discoverer. Under these circumstances, I think it would be well if Jensen, recognising the fictitious state of things attaching to this award, were gracefully to decline its acceptance.

I am, Sirs, yours faithfully,

Clifton, Bristol, Nov. 10th, $1906 . \quad$ W. ROGER Williams.

\section{THE CASE OF MR. PEERS : A MISCARRIAGE} OF JUSTICE. ${ }^{1}$

To the Editors of THE LANCET.

SIRS,-In view of the marked injustice of the verdict in this case and in order to emphasise the sympathy of his professional brethren it is proposed to raise sufficient money to defray the cost of Mr. T. H. P. Peers's defence and to pay the damages awarded. A list will be published in THE LANCET of those gentlemen who have already promised assistance, and in the meantime any further donations will be gratefully received and acknowledged.

I am, Sirs, yours faithfully,

278, Old Kent-road, S.E.

C. H. Pring, M.A. Honorary Treasurer.

\section{MUNICIPAL MUDDLES.}

\section{To the Editors of THE LANCET.}

SIRS,-In The LANCET of Oct. 13th I notice that under the heading "Municipal Muddles" you make reference to the action of the Westminster district surveyor. Would you kindly note that the Westminster District Surveyor is not an official of the Westminster City Council but of the London County Council, and that the whole matter referred to is one which does not in any respect concern the Westminster Oity Council or come within their jurisdiction, but is entirely a matter under the control and administration of the London County Council. I have deemed it necessary to write you as I find that your paragraph has been generally taken to refer to the Westminster City Council.

\section{I am, Sirs, yours truly,}

C. SPENCER-SMITH,

Chairman of the Works Committee of the Westminster Palace-street, S.W., Nov. 13th, 1906.

$$
\text { City Council. }
$$

\section{HYPOCHLORITES PRODUCED BY ELEC- TROLYSIS AS DISINFECTANTS.}

\author{
To the Editors of THE LANCET.
}

SIRs,-You say in your remarks on our recent paper that you believe with Dr. Klein that the hypochlorites are powerful disinfectant agents even in the presence of organic matter. If you will refer to Public Health, October, 1906, you will see that Klein finds for chloros (the strongest solution of hypochlorites offered to the public) a carbolic coefficient in water of $21 \cdot 0$, but in urine $2 \cdot 2$ or $0 \cdot 8$, according to the conditions specified.

Anent your remarks on the inconsistent statements of certain bacteriologists who have worked with the method of standardisation used by us, it is quite true that several observers have obtained varying and various results. These discrepancies are the fault of the observer, not of the method. We have shown conclusively that where the conditions, as enumerated in our paper in Public Health of March, 1906, are strictly observed, the results are uniform. We are, Sirs, yours faithfully,

$$
\text { DAVID SOMMERVILLE. }
$$

Nov. 6th, 1906. J. T. AINSLIE WALKER

\section{THE AMERICAN ROENTGEN RAY SOCIETY.}

\section{To the Editors of THE LANCET.}

SIRS,-Your readers may be interested in some account of the annual meeting of this society which was held at Niagara Falls, New York, on August 29th, 30th, and 31st, at the Cataract Hotel, under the most perfect conditions of weather and surroundings. The attendance of members and visitors amounted to about 200, nearly all the States of the Union being represented as well as some foreign countries. The way to the large room where the meetings were held led through an ante-room arranged for the exhibition of radiographs, which is always an important feature of the annual meeting. No one could help being at once struck with the high degree of excellence which has been attained in this

1 A brief report of this case was published in THE LANCFT of Nov, 10th, 1906, p. 1301. 